\title{
Article
}

\section{'A Very Hell of Horrors'? The Haitian Revolution and the Early Transatlantic Haitian Gothic}

\author{
Hoermann, Raphael
}

Available at http://clok.uclan.ac.uk/13535/

Hoermann, Raphael ORCID: 0000-0001-6156-8431 (2015) 'A Very Hell of Horrors'? The Haitian Revolution and the Early Transatlantic Haitian Gothic. Slavery \& Abolition: A journal of slave and post-slave studies, 37 (1). pp. 183205. ISSN 0144-039X

It is advisable to refer to the publisher's version if you intend to cite from the work. http://dx.doi.org/10.1080/0144039x.2015.1086083

For more information about UCLan's research in this area go to http://www.uclan.ac.uk/researchgroups/ and search for <name of research Group>.

For information about Research generally at UCLan please go to http://www.uclan.ac.uk/research/

All outputs in CLoK are protected by Intellectual Property Rights law, including Copyright law. Copyright, IPR and Moral Rights for the works on this site are retained by the individual authors and/or other copyright owners. Terms and conditions for use of this material are defined in the policies page.

\section{CLoK}

Central Lancashire online Knowledge www.clok.uclan.ac.uk

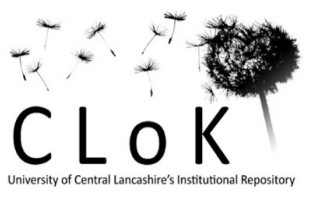


'A Very Hell of Horrors'? The Haitian Revolution and the Early

Transatlantic Haitian Gothic

\section{Raphael Hoermann}

Ascription: Raphael Hoermann is the Marie Curie Intra-European Fellow at the Institute of Black Atlantic Research, School of Language, Literature and

International Studies, University of Central Lancashire, Harrington 248, Preston PR1

2HE, U.K. Email: Rhoermann@uclan.ac.uk

Published online (24/9/2015) in Slavery \& Abolition: A Journal of Slave and

Post-Slave Studies

http://dx.doi.org/10.1080/0144039X.2015.1086083 


\begin{abstract}
:
This article explores the Gothicisation of the Haitian Revolution in the transatlantic discourse during the late eighteenth and early nineteenth centuries. As it argues, the Gothic mode has to be understood as a reaction to the profound challenges that the Haitian Revolution posed to a transatlantic world built on the slave economy. Pro-slavery and pro-colonialist authors demonised this successful slave revolution and one of the first anti-colonial revolutions in modern history by resorting frequently to the 'hegemonic Haitian Gothic.' By contrast, early Haitian leaders and some British radicals appropriated this mode, turning it into the ideologically contrary 'radical Haitian Gothic.'
\end{abstract}

Keywords: Haitian Revolution, Gothic, transatlantic repercussions, proslavery versus radical antislavery authors, Black Atlantic 
In the preface to his 1938 seminal history of the Haitian Revolution, The Black Jacobins, the Trinidadian-born radical writer and activist C.L.R. James famously praised it as 'one the great epics of revolutionary struggle and achievement. ${ }^{1}$ As the only successful slave revolution in modern history and one of the earliest anti-colonial revolutions in the Atlantic world, the Haitian Revolution (1791-1804) stands out as arguably 'the most signal and transformative event in the Age of Revolution. ${ }^{2}$ It forms 'the fourth major, if often forgotten revolution with global implications (in addition to the Industrial, American, and French Revolution). ${ }^{3}$

However, in contrast to the American and French Revolutions, which largely skirted around the issues of race, slavery and colonialism, the Haitian Revolution engaged with them in a radical fashion. It overthrew white European racial oppression and colonial super-exploitation in Europe's most profitable colony. As Michel-Rolph Trouillot has insisted, these fundamental challenges to North Atlantic hegemony and their 'contradiction' of the established master narratives, 'of what the West has told both itself and others about itself,' constitute the main reasons for the revolution's 'silencing' in mainstream historiography. This act in itself marks 'only a chapter within a narrative of global domination' by the North Atlantic world. ${ }^{4}$ The Haitian Revolution further shattered the fundamental 'North Atlantic fiction' that the 'modernity,' which had been globally enforced by the colonial North Atlantic powers and their slave economies, marked the sole and 'universal' version of modernity.

In a strong gesture of defiance to its racist, slave-holding and colonialist neighbours and its French colonial ex-masters, Haiti defined itself as a modern postcolonial state that emphatically rejected both slavery and colonialism. Its imperial 1805 constitution abolished slavery forever (Article 2) and made it illegal for any white person to assume the title of master or own any property (Article 12). In a further defiant gesture, designed to reclaim 'black' from its near ubiquitous racist demonisation throughout the Atlantic world, the constitution in Article 14 stipulated that all Haitian citizens (irrespective of their physiological skin colour) were to be considered 'black.' As Sibylle Fischer highlights, 'black' is emphatically introduced as a 'political rather than a [pseudo-]biological category., ${ }^{, 6}$ 
It is this political re-interpretation of 'blackness' as opposed to white colonialism and enslavement that has led subsequent radical black activists to identify Haiti as the birthplace of a revolutionary Black Atlantic. As the Martiniquan writer Aimé Césaire insists in his anti-colonial epic poem Cahier d'un retour au pays natal (1939), it was 'Haiti where negritude rose to its feet for the first time and said it believed in its own humanity. ${ }^{, 7}$ At the same time, Haiti's prominent place in radical Black Atlantic history has made it a bête noire for transatlantic racists for centuries and has formed a major source for its Gothic demonisation.

\section{The Challenges of the Haitian Revolution and the Gothic}

The Haitian Revolution was unprecedented and posed enormous challenges to an Atlantic world firmly dominated by slavery and colonialism. It evoked a 'Great Fear' of a second slave revolution among the Caribbean colonial powers, including Spain and Britain. Both had unsuccessfully attempted to take possession of Saint-Domingue, which until the revolution had been the most profitable Caribbean colony ${ }^{8}$ The spectre of the Haitian Revolution also haunted the antebellum USA and beyond. ${ }^{9}$ These fundamental challenges to the Atlantic status quo generated a Gothic discourse on the Haitian Revolution in which the spectre of the slave and/or anti-colonial revolution loomed large.

As the African American abolitionist and doctor James McCune Smith asserted as early as 1842 in his Lecture on the Haytien Revolutions, from the moment the revolution began, the discourse on it has been marred by a demonising Gothic rhetoric. Replete 'with exclamations of horror and detestation,' the revolution has often been narrated as a Gothic horror tale, 'named, the "Horrors of Emancipation." ${ }^{10}$ Such Gothic narratives assert that the revolutionary selfemancipation of the slaves and the independence they subsequently fought for so bitterly have plunged the Caribbean's colonial showcase into a cesspool of anarchy and genocidal violence.

How apt McCune Smith's assessment was regarding the Gothicisation of the Haitian Revolution and the demonisation of its victory over slavery and colonialism can be perhaps best be glimpsed by contrasting his title 'The Horrors of Emancipation' to that of an early US epistolary novel on the Haitian Revolution. Penned by Leonora Sansay but anonymously published, Secret History, or the Horrors of St. Domingo (1808) employs the Gothic mode to cast 
the fate of Saint-Domingue as a dire warning of the carnage and ruin that will allegedly result from a reversal of racial power. As the novel insinuates, this will be the inevitable consequence of any revolutionary self-emancipation by the slaves and/or the overthrow of the rule of their colonial masters in the Americas. Long thought to be a collection of genuine letters written by Mary Hassal (Sansay's step-sister) to the then US Vice-President Aaron Burr and to and from her sister Clara, it depicts the final days of colonial Saint-Domingue and the debauchery of the French who are literally dancing on the revolutionary volcano. ${ }^{11}$ As critics have emphasised, the novel also highlights French atrocities committed against the black population and is highly critical of French men in the colony, including the highest generals. ${ }^{12}$ However, most critics will not acknowledge downplay that it reserves some of its most Gothic passages for atrocities that were allegedly perpetrated after the defeat of the French troops by the ex-slaves. While there were historic massacres of the remaining French population (which feature on several white-supremacist and neo-Nazi websites as 'proof' of the incurable savagery of the black race), their extent is contested. ${ }^{13}$ In a trope that is widespread in the Gothic discourse on Haitian Revolution, in Secret History the Haitians are cast as a cross between savages, cannibals, predators and Gothic vampiric 'monsters, thirsting after blood, and unsated with carnage. ${ }^{14}$

However, Sansay's Gothic novel goes still further than the widespread allegation that exslaves were bloodthirsty monsters. Strikingly, Sansay conjures up Gothic fantasies of reverse slavery. As Mary Hassal relates in her 22nd letter, after the defeat of the French troops and her flight from the colony, black soldiers forced 'unfortunate' French women (some of whom had been slaveholders) to toil 'chained' together, 'exposed to the sun, from earliest dawn to setting day, followed by negroes who, on the least appearance of faintness, drove them forward with whips. ${ }^{15}$ There is not the slightest acknowledgement in the text that this 'outrageous' practice of forced labour was deemed totally acceptable across most of the North Atlantic World and had formed the sole basis of Saint-Domingue's enormous wealth for centuries. Obviously, the decisive difference was that then the enslavers were white and the enslaved black, including tens of thousands of women. Sansay's outrage seems directed at the racial reversal of power, the juxtaposition of master and slave and not at slavery as a practice of racialised super-exploitation of Africans. 
The same wilful amnesia marks the depiction of further atrocities that were allegedly committed by the ex-slaves: A former slave of the mother of one of the female prisoners, now an officer in the Haitian army, has her 15 year-old daughter executed, when she refuses to become his wife. He chooses the most horrendous method for this: the 'monster' orders her to be 'hung by the throat on an iron hook in the market place, where the lovely, innocent, unfortunate victim slowly expired. ${ }^{16}$

When Elizabeth Maddock Dillon remarks that this scene 'presents interracial marriage' (or more precisely the threat of it) 'as a form of terror,' this is only the flipside of a much more widespread form of sexual racial terror that this scene silences. ${ }^{17}$ Rape and sexual abuse of black slaves were endemic in all New World slave societies and resisting the colonialists' sexual advances resulted in severe punishment and/or execution. As the Haitian writer Baron de Vastey states in Le système colonial dévoilé (1814), this included paedophilic attacks on 'innocent girl[s] still under [their] mother's wing,' while 'those [women] who put up any resistance to the lustful passion of these men would be made to suffer the most excruciating torment before dying,' including being 'flayed alive' by their jealous rapists. ${ }^{18}$

In sharp contrast to Vastey, what provokes outrage with Sansay's narrator even more than the atrocity itself is the reversal of the racial power relationship from colonial slavery towards postcolonial, post-slavery independence. No longer are brown bodies being routinely tortured, mutilated and executed but also some white ones. While there were massacres of the remaining French after the foundation of Haiti, Sansay's depiction of the gruesome execution of the 'lovely' girl constitutes a - most likely imagined - horrific, voyeuristic and sadistic spectacle of Gothic horror. It both closely mirrors and inverts the horrors of slavery. Significantly, the narrator is not even an 'eyewitness', as she has heard this horror story after her flight from Saint-Domingue to Cuba.

This does not prevent modern-day revisionist historians such as Philippe R. Girard from quoting this tale from this Gothic novel as historical evidence for - what he considers - a 'genocide' perpetrated by the black slaves on the 'white' French. ${ }^{19}$ Whereas there is no objective proof for this kind of atrocity being perpetrated during the massacres of remaining French in 1804 
such as hanging people on meat hooks, there are similar cases documented under the plantation regime. $^{20}$

In fact, with her story Sansay probably alludes to (and juxtaposes it in terms of race and gender) William Blake's powerful plate 'A Negro Hung Alive by the Ribs to a Gallows,' in John Gabriel Stedman's highly popular Narrative of a Five Years Expedition against the Revolted Negroes of Surinam (1796) (figure I). ${ }^{21}$ Stedman in chapter three of the first volume of his Narrative recounts the horrendous executions of defeated rebel slaves in the Dutch colony: 'one man was hanged alive upon a gibbet, by an iron hook stuck through his ribs,' two others burnt at the stake, six 'women broke alive on the rack' and two girls 'decapitated.' Stressing the 'resolution' and bravery of the executed rebels, Stedman depicts these horrendous executions as what he regards as - excesses of the Dutch slave regime. ${ }^{22}$ Blake goes further than Stedman in condemning the entire system of slavery as a Gothic spectacle. He heightens Stedman's Gothic horrors further by adding skulls on poles, a skull missing its lower half and a broken femur missing its other half, which are strewn on the ground, and a slave ship on the horizon behind the gibbet on which the slave hanged by the ribs painfully expires. These bone fragments evoke the 'detritus of the cannibal meal that relates to white abuse rather than black savagery,' as Alan Rice highlights. ${ }^{23}$ Or these broken bones could hint at the common execution method of breaking people on the rack as mentioned by Stedman. At the same time, in constructing 'his own visual triangular trade' between the hanged rebel, the heads on poles and the slave ship, Blake does not just critique slavery, but with the slave ship on the horizon as the visual link, he also implicates the European viewer on the other side of the Atlantic in these atrocities. ${ }^{24}$ First engraved in 1792 at the onset of the Haitian Revolution, Blake's hanged rebel forms both an emblem of the protofascist terror of the plantation regime and of black resistance against it. Albeit brutally stymied, it is still visible in the victim's stoic defiance even as he painfully expires.

Sansay juxtaposes this scenario: now it is the victorious slave rebels who inflict the same horrific punishment upon the defeated former slaveholders (their victim is the daughter of a slaveholder). In a move that is characteristic of large parts of the Gothic discourse on the Haitian Revolution, Sansay aims to blot out the Gothic horrors of slavery by depicting the horrors of emancipation. In fact, the eroticised depiction of the white 'lovely' tortured victim taps into what 
Saidiya V. Hartmann has termed 'the erotics of terror in the racist imaginary' which reach from the pornography of torture of black slaves to post-slavery lynchings. ${ }^{25}$ At the same, the reversal of the race of the victim erases the suffering of tens of thousands of tortured and mutilated black bodies.

It was largely left to contemporary protagonists of the Black Atlantic, such as the mixedrace Baron de Vastey to debunk such pernicious ideological-rhetorical strategies of displacing the terror of slavery by demonising the self-emancipated ex-slaves instead. As he declares in the motto of The Colonial System Unveiled, colonialism and slavery amount to a genocidal horror regime: 'Here it is, revealed, this secret full of horror. The Colonial System [that is the rule of the Whites that is the Massacre or the Enslavement of the Blacks]. ${ }^{26}$ Crucially, as Marlene Daut points out, Vastey's anti-colonial motto constitutes a parody of an assertion by the French excolonist Baron de Malouet that the 'secret revealed, full of horror' consists in 'the liberty of the blacks' and their 'rule' which amounts to 'the massacre or the enslavement of the whites. ${ }^{27}$

Malouet's horrors, the massacres of the whites, and reverse slavery are exactly the terrors that Sansay depicts in her novel. Both envisage a Gothic scenario of racial genocide committed by the black ex-slaves. By contrast, Vastey exposes these horror accounts of black savagery and bloodlust as white fabrications, which were designed to ideologically prop up slavery and colonialism. At the same time, he turns these allegations against their white former masters and their torture system which he viscerally exposes. As Joan Dayan has eloquently argued, prerevolutionary Saint-Domingue could even be regarded as a racialised 'terror regime built on sadist tortures which informed De Sade's fantasies. Governed by 'the law of terror' as the sole de facto law, slaves were routinely exposed to sadistic sexual violence and the most diabolical methods of torture and execution, such as blowing them up or having them smeared in sugar to be eaten alive by ants, and, as Vastey asserts, slowly killed in specially designed 'dungeons. ${ }^{28}$

In sharp contrast to Vastey and Blake, Sansay tacitly invokes the Gothic horror of slavery to demonise the slave revolutionaries rather than to indict their former masters, whose 'depraved imagination' invented the most horrific form of tortures and executions. ${ }^{29}$ As she seems to suggest, slavery and its regime of terror constitute an outrage solely when self-emancipated black people commit these atrocities. Their alleged crime is to subject white people to a similar horror 
regime as that inflicted by the colonists on their slaves, after the ex-slaves have defeated their former European colonial masters.

The underlying panic, which haunts Sansay's novel and many other contemporary texts, consists in the reversal of the racial, colonial power structure of plantation slavery. This inversion forms a major source for the Haitian Gothic. For the first time in the Atlantic world, this upending of the racial power relationship was achieved in post-emancipation Saint-Domingue and, even more decisively, in postcolonial Haiti, as it is, for instance, reflected as late as 1900 in the title of Hesketh Prichard's travelogue Where Black Rules White. This reversal followed the revolutionary overthrow of the colonial slave plantation society in the richest colony in the Caribbean. The Haitian Revolution could thus even be considered the most radically social revolution during the Age of Revolutions, since it destroyed the entire social and economic system of the colonial slave society where it had been most profitable..$^{30}$

This 'dual revolution,' the slaves' revolutionary self-emancipation from both slavery and colonialism, shocked the transatlantic world and fuelled the Gothic discourse on the Haitian Revolution. ${ }^{31}$ For these racialised socio-economic institutions formed the mainstays of the transatlantic order and the source of much of the wealth of several of the North Atlantic countries. As the subsequently deposed representative of the Organisation of American States, Ricardo Seitenfus, asserted in 2010, the slaves' double liberation constituted a crime of 'lèse-majesté' in a world dominated by slavery and colonialism. Forming Haiti's 'original sin' until today, Western powers have attempted to redress the country's revolutionary transgression, of defeating the then global superpowers Spain, France and Britain, through ostracism, isolation as well as several interventions, invasions and occupations. The US military occupation (1915-1934) and the ongoing (since 2004) MINUSTAH UN stabilisation mission feature among them. ${ }^{32}$

These military and diplomatic interventions were accompanied by an equally vicious rhetorical and cultural warfare with the Gothic mode playing a major part in it. For instance, during the US Occupation, American writers produced a plethora of Gothic texts. Some hark back to the Haitian Revolution. For instance, Eugene O'Neill's highly successful play Emperor Jones (1920) (which was turned into a film in 1933 staring the African American actor and activist Paul Robeson) racially caricatures any pretension to 'black majesty', not least by alluding to the slave- 
rebels turned Haitian emperor or king, Jean-Jacques Dessalines, Henri Christophe and Faustin Soulouque. G. W. Hutter penned an atrocious Gothic anti-revolutionary short story Salt Is Not for Slaves (1931), in which slave rebels are turned into zombies as punishment for their insurrection. ${ }^{33}$ These and other examples provide clear evidence for an 'established pattern of pathologising Haiti' ${ }^{34}$

Since its onset, then, the Haitian Revolution and the 'black' state of Haiti have been viciously demonised. Some scholars have vividly illustrated how Haiti has received among the most negative portrayals and coverage of any country in North Atlantic discourse. ${ }^{35}$ Often of dire quality, these representations have depicted Haiti as the epitome of the antithesis of Western 'civilisation' and 'culture.' Michel-Rolph Trouillot remarks that it has been configured as a 'unique,' exceptional place that has been labelled with negative epithets such as 'bizarre, unnatural, odd, queer, freakish, or grotesque. ${ }^{36}$ As Noam Chomsky astutely observes, Haiti routinely figures as a Gothic hellhole, 'miserable, horrifying, black, ugly. ${ }^{37}$ Haitian-American anthropologist Gina Athena Ulysse further maintains in her recent intervention Why Haiti Needs New Narratives that the origins of this racist demonisation, of its 'blackness,' are to be found in the Haitian Revolution and its overthrow of colonialism:

Haiti and Haitians remain a manifestation of blackness in its worst form, because, simply put, the unruly enfant terrible of the Americas defied all European odds and created a disorder of all things colonial. Haiti had to become colonialism's bête noire if the sanctity of whiteness were to remain unquestioned. ${ }^{38}$

Ulysse's reading of the Haitian Revolution as a violation of the 'sanctity of whiteness' also helps to understand the conspicuous horror attached to scenarios of reverse slavery and the mutilation and torture of white bodies. Simultaneously mirroring and obscuring the routine mass torture of black bodies these alleged atrocities constitute one of the most visceral markers how Haiti has forever violated and stained the nimbus of white supremacy.

The Gothic narrative mode has featured as major rhetorical-ideological weapon in this continuing campaign against Haiti and its perceived transgressions from the Haitian Revolution up 
to the present. Even as recently as the discourse on the 2010 Haitian Earthquake, the revolution frequently features as the source of all evil that has befallen Haiti since. ${ }^{39}$

\section{The Hegemonic and the Radical Haitian Gothic}

While the Gothicisation of Haiti and its revolution is ongoing, this article focuses on the early Haitian Gothic. Matthew Clavin situates its roots mainly in the bloody events of the revolution, in 'the thirteen years of bloodshed between half a million black slaves, tens of thousands of mulattoes [sic], and French, English, and Spanish settlers and soldiers. ${ }^{40}$ He further argues that 'commercial' considerations played a key role in adopting conventions of the then highly popular Gothic mode. ${ }^{41}$ Gretchen Woertendyke regards the Gothic in narratives of the Haitian Revolution largely as a literary mode. ${ }^{42}$ Ellis Markman shows how the myth of zombi as well as the eponymous Western horror trope is strongly rooted in the horrors of plantation slavery and the resistance against it. ${ }^{43}$ Similarly, H.L. Malchow regards Frankenstein's monster in Mary Shelley's Frankenstein, or, the Modern Prometheus (1818) as an allegory for the Caribbean rebellious slave, in particular for the Haitian rebels. ${ }^{44}$ As Lisbeth Paravisini-Gebert claims, the Haitian Revolution constitutes 'the foundational narrative of the Caribbean Gothic, $[\ldots]$ the obsessively retold master tale of the Caribbean's colonial terror. ${ }^{45}$ While she mainly limits it to literature, the Haitian Gothic affects the entire discourse across numerous genres, reaching from literature, pamphlets, history as well as visual media, such as caricatures and film. As one of the few critics, Dayan goes beyond literary texts as she investigates links between Enlightenment scientific racist discourse, slavery, the Haitian Revolution and the Gothic. ${ }^{46}$

Without discounting the historical, factual horror and violence of both plantation slavery and the struggles of the Haitian Revolution as factors that led to rise to the Haitian Gothic, this article instead emphasises the severe challenges that revolution posed to the North Atlantic status $q u o$ as decisive contributing factors. These included the threat to (neo)-colonialism and the transatlantic slave economy, to notions of savagery and civilisation, to fictions of racial hierarchies such as white biological or cultural superiority, and the Eurocentric conception of the Enlightenment and modernity. As studies of the recent Haitian Turn in transatlantic studies have contended, the Haitian Revolution harboured an 'alternative modernity,' which was diametrically 
opposed to the racialised, colonialist and capitalist North Atlantic modernity and thus had to be suppressed. ${ }^{47}$ The Haitian Gothic has therefore to be considered in the light of these challenges rather than the 'natural' mode in which to narrate a bloody and protracted slave revolution.

To define this term, the 'Haitian Gothic' is an ideological-narrative mode that encompasses various media and makes excessive use of tropes of horror and terror in narrations of Haiti, in particular of the Haitian Revolution. It is largely employed by non-Haitians. Importantly, the Haitian Gothic is not limited to Gothic novels and unlike most classic Gothic novels, it does not necessarily involve the supernatural. The horror trope of the zombie marks an important exception, as exploited, for instance, by Madison Smartt Bell in his horror trilogy of neo-Gothic novels on the Haitian Revolution. ${ }^{48}$

Furthermore, it is important to distinguish between two main strands of the Haitian Gothic: Clavin has asserted that the eighteenth to mid-nineteenth century North Atlantic Gothic discourse on the Haitian Revolution remains ideologically 'bifurcated.' It is split between pro- and anti-slavery authors, between those who "warned of a repetition of the "horrors of St. Domingo", as opposed to the abolitionists who argued the slaveholders had 'sown the seeds of their own destruction. ${ }^{49}$ Both conjured up the Gothic spectre of the Haitian Revolution to advance their causes. As David Brion Davis highlights, the 'imagery of the great upheaval hovered over the antislavery debates like a bloodstained ghost. ${ }^{50}$

This article aims to significantly extend and revise Clavin's claim. The Haitian Gothic on the whole can roughly be divided into two major ideological camps: the hegemonic and the radical Haitian Gothic. The radical Haitian Gothic goes considerably further than Clavin's abolitionist Gothic. It explicitly endorses the revolutionary self-emancipation of the slaves from both slavery and colonialism. In sharp contrast, the Gothic discourse of some of the liberal abolitionists Clavin mentions, such as Thomas Clarkson, does not approve of the slaves' revolutionary self-liberation. Unlike Philip Kaisary, who has recently divided twentieth-century literature and art on the Haitian Revolution into 'radical' and 'conservative,' to distinguish the Haitian Gothic 'hegemonic' is preferable to 'conservative. ${ }^{51}$ The term hegemonic with its Gramscian overtones highlights more emphatically than does conservative that the dominant Gothic mode ideologically supports the ruling capitalist order and the Atlantic status quo. This explains how many avowedly 
liberal writers, such as Victor Hugo in his novel on the Haitian Revolution Bug-Jargal (1826), were proponents of the hegemonic Gothic.

In fact, the vast majority of the Haitian Gothic belongs to this hegemonic variety, since it conforms to the ideologies of the dominant classes and forces in the North Atlantic world. Here Haiti and its revolution often occupy the place of the antithesis of 'Western civilisation.' As the veteran African American abolitionist (and former ambassador to Haiti) Frederick Douglass remarks in his Lecture on Haiti, which he delivered at the African-Methodist church, Quinn Chapel, in Chicago on 2 January 1893, the challenges emanating from the Haitian Revolution have made Haiti a 'source of terror and alarm' to a transatlantic socio-economic order based on racial discrimination and exploitation. ${ }^{52}$ Not only did it challenge the Atlantic status quo but its revolutionary self-emancipation also exploded the pernicious myth of emancipation of a gift bestowed generously upon the supplicant slave by the white master: 'the freedom of Haiti had was not given as a boon, but conquered as a right! [Applause] ${ }^{53}$ Haiti's revolutionary selfemancipation is the polar opposite of - what Marcus Wood has termed similarly to Douglass - the 'horrible gift of freedom,' emancipation from above, hypocritically bestowed upon the slaves by their colonial enslavers. ${ }^{54}$ Forming such a dangerous precedent of black revolutionary liberation, Haiti had to be contained. Containment happened not merely in diplomatic and economic, but also in rhetorical terms: the demonising discourse depicts Haiti as a Gothic place of darkness, 'a very hell of horrors,' as Douglass highlights the hyperbole of the hegemonic Haitian Gothic. ${ }^{55}$

However, at the same time as Douglass is exposing the hegemonic Gothic, he is surreptitiously introducing the radical Haitian Gothic. Defending the Haitian Revolution against its detractors, he implies that the ex-slaves in the War of the Independence had to resort to revolutionary terror in order to ward off re-enslavement: 'The souls of [Haiti's enemies] by the thousands were speedily sent into eternity, and their bones were scattered on the mountains of Haiti, there to bleach, burn, and vanish under the fierce tropical sun. ${ }^{56}$ The vanishing remains of Napoleon's army sent to restore slavery serve as Gothic reminders not just of the terror of the Haitian Revolution but also of the white colonial hubris that believed that slavery and colonialism could continue unchallenged. However, Haiti showed the fallacy of this thinking. Its revolutionary 
strength, here symbolised by the powerful tropical sun, has even eradicated the last traces of its colonial oppressors, their bones.

Douglass further co-opts the Haitian Gothic for a vision of universal Black Atlantic emancipation. He cast the bleaching and vanishing white bones of the white invaders as a potent Gothic symbol for the successful self-emancipation of the diasporic blacks across the Black Atlantic, not merely from slavery but also from colonialism and racial oppression. Semi-detached from the actual country, for Douglass, 'Haiti' with its tremendous revolution has become a symbol for the power of manly revolutionary struggle and emancipation across the entire Black Atlantic, for 'Negro Manhood, Negro bravery. ${ }^{57}$ Echoing Dessalines' constitution that stipulates that all Haitians are to be considered black, Douglass casts 'the only self-made Black republic in the world' as a beacon for black emancipation across the Atlantic: 'Haiti is the black man's country, now forever. [Applause.] ${ }^{58}$

Yet it is exactly this avant-gardist role of Haiti for the genealogy of Black Power that marks its sin in the eyes of its detractors: The North Atlantic world has 'not yet forgiven Haiti for being black,' for achieving the revolutionary self-emancipation of its black slaves and establishing a state that affirms the political power of 'blackness' in a racist and colonialist world. These perceived transgressions mark a major source of the hegemonic Haitian Gothic. ${ }^{59}$

\section{'Like so many Famished Tygers Thirsting for Human Blood': Demonising the Haitian}

\section{Revolution}

Both the genealogy of the hegemonic and the radical Haitian Gothic stretches back to the Haitian Revolution. The origin of the hegemonic Haitian Gothic can even be traced back to the contemporary discourse on the 1791 slave revolt which started the revolution. Pro-slavery authors made a concerted effort to demonise the rebels by resorting to the Gothic mode. However, when the ex-slaves won their bitterly fought for independence, they appropriated the Gothic demonisation of them by their former colonial masters and turned it against them.

A fundamental text for the formation of hegemonic Haitian Gothic, on which most subsequent texts on the Haitian Revolution have drawn, is Discours des colons (1791). It marks the first propaganda pamphlet by colonists from Saint-Domingue about the incipient revolution. It 
very consciously and consistently employs the Gothic mode. Highly popular, it had four editions in its English translation. Incessantly, it highlights the 'horrors' and 'terror' that the deeds of the rebels evoke. ${ }^{60}$ Moreover, on several occasions, it self-consciously flags up its use of the Gothic narrative mode, for instance, when its authors assert that "nothing, one would think, could deepen the horrors of this recital. ${ }^{61}$ This admission serves as a preamble to several anecdotes that relate how it was the best-educated and allegedly best-treated slaves who led the revolt. These tales, which are 'marked with features of a still more dreadful character,' as the authors metatextually comment, purportedly provide proof of the absurdity of the abolitionists' claims that the horrors of slavery are the cause of slave revolts rather than abolitionist propaganda. ${ }^{62}$

To demonise the abolitionists and the slave rebels, the pamphlet relates a litany of shocking atrocities that the rebels had allegedly committed, such sawing a carpenter in two and raping white women on the dead bodies of their husbands. Among them the apocryphal horror trope of the impaled infant carried as the banner by the rebels stands out 'Their standard was the body of a white infant impaled upon a stake. ${ }^{63}$ It forms a Gothic master trope that haunted transatlantic 'transatlantic oral and print culture for generations [...] evoking the horrors of a second Haitian Revolution. ${ }^{, 64}$

In 1797, the first British historian of the still ongoing Haitian Revolution, the MP and Jamaican planter Bryan Edwards reproduced many of these atrocities stories. As with A Particular Account, whose Gothic rhetoric he imitates, the terror that haunts Edward's text is the twin spectre of the overthrow of both slavery and colonialism in the Caribbean. He employs the Gothic mode to rhetorically and ideologically demonise the revolution. Even more than the authors of $A$ Particular Account, he is conscious of this strategy. For instance, when he retells the anecdote of the impaled infant, he not only italicises the sentence as in A Particular Account, but emphasises its horror further by adding in parentheses: 'horrid to tell!! ${ }^{65}$ As he highlights in hyperbolic language, his account strives to combine all imaginable horrors into a Gothic diorama of Haitian Revolution: 'a combination of horrors; - wherein we should behold cruelties unexampled in the annals of mankind; human blood poured forth in torrents.' Moreover, he also presents the desired emotional effect of his narrative on the readers when he casts the slave rebels as 'savage men, let loose from restraint, exercising cruelties, of which the bare recital makes the heart recoil. ${ }^{, 66}$ 
Recounting the beginning of the 1791 revolt, he conjures up a further horror scenario of the colony's descent into 'African barbarism':

Upwards of one hundred thousand of savage people, habituated to the barbarities of Africa, avail themselves of the silence and obscurity of the night, and fall on the peaceful and unsuspicious planters, like so many famished tygers thirsting for human blood. Revolt, conflagration, massacre, every where mark their progress; and death in all its horrors [...] await [sic] alike the old and the young, the matron, the virgin and the helpless infant. ${ }^{67}$

Edwards employs a mixture of sentimentality and horror to drive home his less than subtle points that the advance of these 'savage monsters' must be routed at all cost. African 'progress' equals descent into savagery. He concurs with the authors of $A$ Particular Account, who warn that SaintDomingue would present a 'picture of all the atrocities of Africa' if the slaves manage to take over the colony. ${ }^{68}$ But Edwards with his apology for slavery is also in line with modern-day Nazis who claim that by ' 1806 the entire White [sic] population had been butchered and the bloodstained island returned to the jungle. ${ }^{69}$ Only the allegedly civilising influence of European plantation slavery could prevent this descent into African barbarism, Edwards insists. He dehumanises the rebels further as he likens them to what he wrongly identifies as gruesome African predators, 'tygers thirsting for human blood,' a metaphor with highly cannibalistic overtones.

Drawing upon the long-established Gothic iconography of the slave revolt, the slaughter of the innocents, Edwards alleges that the slaves kill indiscriminately, irrespective of sex and age, 'the peaceful and unsuspecting planter' as well as women and children. In the same way, $A$ Particular Account also recounts how 'men, women, the infant, and the aged, expired indiscriminately under the knife of the assassins. ${ }^{70}$ In both texts, this massacre of the 'innocent' functions as a supreme marker of the allegedly innate African savagery of the rebels.

\section{'These Tigers Thirsting for Human Blood': Haiti Writes Back}

The hegemonic use of the early Haitian Gothic tends to demonise the rebels, sentimentalise and sanitise slavery and thus exonerate the planters' reign of terror. However, some radical writers early on appropriated the hegemonic Gothic and employed it for ideologically opposite ends: for 
example, to indict the terror of plantation slavery and the horrors and atrocities of the French invasion army and to extol the rebels' heroism in their struggle against slavery and colonialism.

One of the first sustained uses of this radical Gothic can be found in the middle section of Dessalines' tripartite 1804 Haitian Declaration of Independence, which was probably largely written by his mixed-race secretary Boisrond-Tonnerre. Even though the most immediate ideological goal of this section was to justify to the Haitians the impeding massacre of the remaining French, at the same time, it marks arguably the first emphatically postcolonial manifesto. As such it was addressed to the wider Atlantic World as much as to Haiti's new citizens. $^{71}$ As its authors declare, Haiti's colonial spectre must be exorcised, since for now 'the pall cast by the French name still hangs over our lands,' even though the 'barbarians who have bloodied [our country] have been expelled. ${ }^{, 72}$ Inverting the colonial trope that casts the (ex)-slaves as African barbarians, now the French, the Europeans, stand accused of savagery.

The declaration's postcolonial thrust is mirrored rhetorically in the reversal and appropriation of tropes of the hegemonic Haitian Gothic. It inverts Gothic tropes such as the slaughter of the innocent as well as the comparison of the rebels to bloodthirsty tigers. Dessalines and Boisrond-Tonnerre turn the Gothic rhetoric aimed at demonising the (ex)-slaves against its creators, the European colonisers. Co-opting the iconography of the slave revolt, the trope of the slaughter of the innocent, they remind the Haitians how 'your wives, your husbands, your brothers, your sisters, [...] your children, your suckling babes' have become 'prey of these vultures,' that is the French. Radicalising and appropriating the comparison of the rebels to 'famished tygers thirsting for human blood,' Dessalines and Boisrond-Tonnerre invert the metaphor. They portray the French 'assassins' of the families of the new citizens as predators: they form 'the tigers yet dripping with their blood. By co-opting the Haitian hegemonic Gothic and radicalising it, they call on their audience for speedy 'vengeance' on French for their crimes, a call which soon afterwards would translate into massacres of the remaining French population. ${ }^{73}$

The subsequent proclamation justifying these massacres, signed by Dessalines and the mixed-race secretary Chanlatte, is characterised by an even more heightened Gothic rhetoric. The massacres are presented as a vital act of cleansing from colonialism and a preventive attack to forestall any attempts to re-colonise Haiti. The juxtaposed Gothic image of the slaughter of the 
innocents reappears as a horrible prospect that justifies the massacres of the French. To stop the French 'sacrilegious horde attempting our destruction, without distinction of sex or age,' it was necessary 'to plunge our desperate daggers into their bosoms.' The revolutionary radicalness of their rhetoric becomes evident if it is compared to pro-slavery rhetoric. For instance, Edwards alleges in the preface to his history that the slaves were driven by abolitionists 'to plunge their daggers into the bosoms of unoffending women and helpless infants. ${ }^{74}$ With Chanlatte/Dessalines, the Europeans were no longer innocent victims of the savage rage of the Afro-Caribbean slaves, but their destruction is presented as a justified, anti-colonial revolutionary act, since the French were allegedly plotting the extermination of the Haitians. While such allegations may seem far-fetched, it is important to remember that in 1802 during the War of Independence, the French commander General Leclerc declared that he was fighting a 'war of extermination' and suggested to Napoleon that 'you have to destroy all the negroes of mountains,' but only 'half of those of the plains,' as these apparently were still needed as slaves to work the plantations. $^{75}$

After the French defeat, the war of words continued. The Haitians exposed the hegemonic Haitian Gothic and radically appropriated it to justify the extermination of the remaining colonisers. Resorting anew to the inverted metaphor of the French (rather than the slave rebels) as savage predators, Dessalines and Chanlatte declare that Haitians ought to fulfil their sacred and manly duty 'by exterminating these tigers thirsty for blood.' Possibly responding to this postcolonial writing back, the highly unreliable white eyewitness of the massacres, the ex-planter Pierre Etienne Chazotte describes Dessalines on the eve of massacres surveying 'the white people with the ferocious eyes of a famished tiger. ${ }^{, 76}$ Of course, the cannibalistic connotation of a tiger hungry for white flesh mark him out as the ultimate savage, in the same way as the colonists in $A$ Particular Account had demonised the revolutionary determination of the 1791 slave rebels as 'the fury of the cannibals. ${ }^{, 77}$ By contrast, in a further reversal of the colonial discourse, Dessalines and Chanlatte re-assign this ultimate, colonialist marker of non-European 'savagery' to the former European colonial masters. When they cast the French as 'true cannibals,' they subvert centuries of colonial discourse, which had portrayed the Caribbean as the epitome of cannibalism. ${ }^{78}$ Not only is the word 'cannibal' derived from 'Carib,' the generic name given to many tribes of 
Amerindians in the region, but this alleged marker of utter savagery also served as ideological legitimisation for the enslavement of the Caribbean's native population and later of kidnapped Africans. ${ }^{79}$ As Mimi Sheller explains, the colonisers called those Amerindians " "cannibals" who staged resistance and could thus be enslaved or killed. ${ }^{80}$

In their juxtaposition of the Gothic trope of the cannibal to denote the coloniser and enslaver, Dessalines and Chanlatte partake in an early Black Atlantic and transatlantic radical counter-discourse. As Alan Rice suggests, this juxtaposed the allegations of cannibalism and savagery levelled against diasporic Africans and raised 'the polemical point that slavery is a cannibalistic process, a form of economic cannibalism (or vampirism) that sucks the life-blood of the enslaved Africans.' ${ }^{81}$ These view anticipate Sheller's contention that slavery marked 'the consumption of African bodies. ${ }^{82}$ This vampiric and cannibalistic connotation is also clearly present in the appropriation of the Gothic metaphor of the French as 'tigers thirsty for blood.' Moreover, it also appears in the radical metaphor of the oppressor as leeches, which is here applied to the colonists, who 'have fattened themselves on our sweat, these insatiable leeches. ${ }^{, 83}$

As it becomes apparent in the course of the declaration, Dessalines and Chanlatte aim further than merely to justify the massacres of the remaining French. On top of the literal revenge, which they justify as a form of Old Testament justice, 'crime for crime, outrage for outrage,' Dessalines enacts a symbolic revenge for the crimes of colonialism and slavery across the New World. Famously, he stylises himself as the avenger of all 'America.' This includes not merely the enslaved Africans in the Americas but also the exterminated indigenous population who are memoralised in the Taino name for new state, 'Haiti.'

However, Dessalines reserves the most Gothic passages for a stark warning to France (or any other European colonial power) not to attempt another invasion of the country. Harnessing the power of the Gothic in his rhetorical warfare, Dessalines aims to strike fear in the hearts of potential invaders. He promises 'ruin and terror to the wicked,' and warns of the 'sixty thousand man' strong Haitian army that is 'burning to offer another holocaust to the manes of their slain brothers.' The Gothic rhetoric here does not just simply function as an ideological weapon, but it recalls spectres of the twin terror of slavery and colonialism which Haiti has just overthrown, at tremendous human cost. Tapping into the old radical biblical imagery of 'the axe $[\ldots]$ laid unto 
the root of the trees' (Matthew 3:10), they assert that the hands of the Haitians, 'have carried the axe onto the ancient tree of slavery and prejudices.' The Haitian Revolution has not just marked a decisive material victory against New World Slavery, but, at least as importantly, an ideological strike against the racism, the 'prejudices' that underpins it. By combatting these forces, Haiti has emerged as the epicentre of a revolutionary Black Atlantic. As such, Dessalines and Chanlatte's threat to the European colonial nations at the same time marks a clarion call for anti-colonial liberation, to rid the New World of all the enslavers and colonialists that blight it: 'tremble tyrants, usurpers, plagues of the New World, our daggers are sharpened, your torments are ready! ${ }^{84}$

\section{Robert Wedderburn: Towards a Gothic Rhetoric of Transatlantic Revolution}

It took more than a decade for a similarly radical appropriation of the Haitian hegemonic Gothic to emerge outside of Haiti. The mixed-race radical, Black Atlantic abolitionist and revolutionary agitator, Jamaican-born Robert Wedderburn, employs the radical Haitian Gothic in his short-lived journal The Axe Laid to the Root: or a Fatal Blow to the Oppressors, being an Address to the Planters and Negroes of the Island of Jamaica (1817). As the title suggests, which uses the same radical-biblical imagery of the axe laid unto the tree as Dessalines, he marries contemporary British radical with Black Atlantic revolutionary rhetoric. Similar to Dessalines, in this defence of the revolution, Wedderburn also debunks the sentimental pro-slavery Gothic rhetoric of the innocent planters and their savage assailants. He juxtaposes it with a forceful Gothic revolutionary rhetoric, which casts the Haitian Revolution as the primal scene of transatlantic emancipation:

Prepare for flight, ye planters, for the fate of St. Domingo awaits you. Get ready your blood hounds, the allies which you employed against the Maroons. Recollect that fermentation will be universal. [...] They will be victorious in their fight, slaying all before them $[\ldots]$ They will slay man, woman, and child, and not spare the virgin, whose interest is connected with slavery, whether black, white or tawny. [...] The holy alliance of Europe, cannot prevent it, they have enough to do at home, being compelled to keep a standing army in the time of peace, to enforce the civil law. My heart glows with revenge, and cannot forgive. ${ }^{85}$

Wedderburn utilises the spectre of the Haitian Revolution to write a Black Atlantic discourse of revolutionary liberation spanning Haiti, Jamaica, and the British Isles. Similar to

Dessalines/Boisrond-Tonnerre, Wedderburn does not merely turn the Haitian Gothic against his 
enemies, but also appropriates it as an ideological weapon in his rhetorical campaign for revolution. Like them, he confronts pro-slavery authors such as Edwards who decried in Gothic language the fate of the innocent planters and their families who were assailed by - what were demonised as - African monsters. By contrast, Wedderburn exhorts the would-be slave revolutionaries not to spare anyone, irrespective of gender, age or even race. For Wedderburn, slavery constitutes a racialised system of super-exploitation that permeates an entire society across colour, class and gender lines. As he insists, there cannot be any innocent party that is involved with the system of terror which was plantation slavery, a 'régime of calculated brutality and terrorism. ${ }^{86}$ The Horrors of Slavery (the title of Wedderburn's 1824 abolitionist pamphlet) can only be overthrown in a slave revolution that employs terror as one of its weapons. This revolution will be fuelled by just 'vengeance' for terrible acts of violence inflicted upon the Afro-Caribbean slaves that can never be forgiven.

Without any qualm whatsoever, Wedderburn embraces terror as a vital weapon in the revolutionary overthrow of systems of racial and socio-economic violence and exploitation. In fact, what Wedderburn envisages is a revolution which will redistribute the land and of which the slaves' garden plots will form the kernel. As he admonishes the Jamaican slaves: 'Above all, mind and keep, possession of the land you now possess as slaves; for without that, freedom is not worth possessing. ${ }^{, 87}$

Obviously, such ideas were anathema to Dessalines who desperately tried to preserve the plantation economy. Yet Wedderburn was not just writing about the Caribbean, but he also agitates for a British revolution that will include a radical a redistribution of the land. ${ }^{88}$ This constant dual reference in this rhetoric distinguishes Wedderburn here from most of his fellow early communist 'Spenceans' and other radicals. These referred largely to metaphorical slaves, Britain's landless proto-proletariat, and not, unlike Wedderburn, to the chattel slaves in the West Indies.

In doing so, Wedderburn creates a truly transatlantic Gothic poetics of social revolution. Writing primarily for a London radical audience, he is calling for a proto-proletarian revolution. He suggests that British revolutionaries, inspired by the Haitian Revolution, will overcome Britain's 'standing army.' 'Universal fermentation,' this seems Wedderburn's hope, will 
eventually lead to transatlantic revolutionary universal liberation which will end race and class oppression. At the same time, Wedderburn casts himself as a revolutionary fighter closely linked to the slave rebels. While they use their plantation tools, the 'bill-hooks' in their revolutionary struggle, Wedderburn's London printing press forms his 'engine of destruction' from which he shoots his 'arrow stained with Africans' blood. ${ }^{89}$ As Alan Rice describes Wedderburn's rhetorical and ideological trajectory: 'Inspired by the rebellion on San Domingo and the activities of the rebellious maroons in Jamaica, Wedderburn uses a black Atlantic discourse of radicalism to incite revolution on the streets of the imperial capital. ${ }^{90}$ While his immediate target was London's impoverished proto-proletarians, Wedderburn inextricably links slave revolutionaries and rebels in the Caribbean with proto-proletarian revolutionaries in Britain. The latter, he hopes, will be recruited among the impoverished artisans and the army of workers toiling as 'Slaves' in the 'Cotton Factories. ${ }^{91}$ At the same time, Wedderburn presents the Haitian Revolution as the blueprint for subsequent slave and anti-colonial revolutions in the Caribbean. As a handbill for debate of 16 August 1819 in Wedderburn's chapel states, the aim is for 'another sable Nation freeing itself by the Dagger from the base Tyranny of their Christian Masters. ${ }^{92}$

Wedderburn thus appropriates the Haitian Gothic to call for a dual transatlantic revolution: a slave revolution in the Caribbean and a proletarian one in Britain. It is not only the 'fate of St. Domingo' that should serve as an inspiration for the British proto-proletariat, but also the continued resistance by the Caribbean slaves. The Caribbean slaves who 'have fought in some instances for twenty years for their 'Liberty" are held up as an example to the 'Britons who boasted such superior feeling and principles $[\ldots]$ to fight now but for a short time for their Liberties. ${ }^{93}$ It was the gravest privation of the 'sacred rights of man' in the slave economy that has generated the fiercest struggles for freedom. ${ }^{94}$ As Wedderburn suggests, the concept of universal revolutionary emancipation that aims for comprehensive socio-economic liberation beyond mere political freedom was forged in the Caribbean. While he considers this as the goal of all slave resistance, including those of the Jamaican Maroons, Saint-Domingue with its successful revolution occupies a prominent place in this struggle for universal emancipation.

With this juxtaposition of the North Atlantic world and the Caribbean, Wedderburn anticipates tenets of what has become know as the 'Haitian Turn' in transatlantic studies, which 
reverses the hierarchy between metropole and periphery. As Nick Nesbitt contends, through their act of revolutionary self-emancipation, the Haitian slave revolutionaries on the periphery opened up the utopian possibility of an alternative modernity which campaigned for revolutionary 'universal emancipation' of all its members irrespective of race and class. As Sibylle Fischer emphasises, this formed a counter-narrative to the hegemonic colonialist and capitalist North Atlantic modernity. However, the Haitian Revolution's 'alternative modernity' was ‘disavowed,' in a double sense, not acknowledged and repressed and marginalised. ${ }^{95}$ In his insistence on the revolutionary spirit of African diasporic slaves in the Caribbean and his anti-capitalism, Wedderburn belongs to this alternative, marginalised modernity. Not only does he radically endorse the Haitian Revolution and but also is he committed to further revolutionary transatlantic emancipation, from race and class oppression.

Wedderburn develops his affirmative scenario of universal transatlantic revolutionary emancipation, of 'universal' 'fermentation' as he calls it, further in the 'sermons' that he preached in his chapel on Hopkins Street in Soho in London. Even through the garbled notes of the Home Office spies, we can detect a constant, conscious slippage, a blurring of the distinction between slave revolution and proto-proletarian revolution in Britain. Using further Gothic imagery, he prophesies that Britons in the impending 'slaughter for Liberty' will have 'to kill their masters to gain their Liberty' and escape 'Slavery.' At the same time, he also debates the question, 'Has a Slave an inherent right to slay his Master who refuses his Liberty'?; a right which in his eyes the slaves in the Haitian Revolution had affirmed. ${ }^{96}$ After the 'congregation' had voted in favour of this motion, the British-Jamaican mixed-race revolutionary Wedderburn declared cheekily: 'well Gentlemen I can now write home and tell the Slaves to murder their Masters as soon as they please. ${ }^{97}$ In this piece of truly Black Atlantic discourse, the black Atlantic radical suspended between London and his West Indian origins conflates Britain and the Caribbean, the black and white 'slaves' and their revolutionary resistance. Wedderburn constitutes an avant-garde figure, both in the radicalness of his conception of a revolutionary Black Atlantic, his dual rhetoric and his radical appropriation of the Haitian Gothic. This merges race and class without playing out one against the other, unlike Cobbett in his Gothic racist fantasies of the Haitian Revolution. ${ }^{98}$ 
While his dual Black Atlantic rhetoric, the merging of slave and proto-proletarian rebels sets Wedderburn apart, he does share with most proponents of the radical Haitian Gothic, the fearless and fierce counterattack on those who have demonised black resistance. These include not merely the (ex-)colonists themselves but also the ideologues of colonialism and oppression. The radical Haitian Gothic amounts to a belligerent anti-colonial and postcolonial writing-back avant la lettre with the printing press serving as its "engine of destruction. ${ }^{99}$ As Baron de Vastey insists, with the newly established 'Haytian presses', the African diaspora will not merely 'unveil the crimes of colonists.' But it also will combat its ongoing demonisation by exposing 'the most absurd lies invented by the prejudice [...] of our oppressors.' To 'write back against [Haiti's] detractor' forms a major ideological motive that drives the majority of the radical Haitian Gothic from the early nineteenth to the later twentieth centuries. ${ }^{100}$ 
Figure I William Blake 'A Negro hung alive by the Ribs to a Gallows' (1792), in John Gabriel Stedman Narrative, of a Five Years' Expedition, against the Revolted Negroes of Surinam (London: J. Johnson, Second Edition, 1813), vol. 1, 163, out of copyright, public domain 


\section{Acknowledgements}

I am very much indebted to the Professor Marlene L. Daut for insightful comments regarding early literature on the Haitian Revolution, to Professor Alan Rice for his comments, in particular on the Black Atlantic counter-discourse on cannibalism, and his encouragement, Professor Gina Athena Ulysse for facing the horrors of the texts and providing helpful references and Dr.

Miranthi Huwae for anatomical advice. I am also grateful to Dr. Margaret Hiley-Kroeger for her proofreading and my research assistant Dyana Saad for formatting the notes. This research has been partly funded by a Marie Curie Intra-European Fellowship awarded by the European Commission and by the German Research Foundation. 


\section{Notes:}

${ }^{1}$ C.L.R. James. The Black Jacobins: Toussaint L'Ouverture and the San Domingo Revolution (1938; London etc., 2001), xviii.

${ }^{2}$ Lindsay J. Twa, 'Jean-Jacques Dessalines: Demon, Demigod, and Everything in Between,' Romantic Circles: Circulations: Romanticism and the Black Atlantic,

http://www.rc.umd.edu/praxis/circulations/HTML/praxis.2011.twa.html [accessed 7/3/2015]

${ }^{3}$ Srinivas Aravamudan. Tropicopolitans: Colonialism and Agency, 1688 - 1804 (Durham: Duke

University Press, 1999), 292.

${ }^{4}$ Michel-Rolph Trouillot. Silencing the Past: Power and the Production of History (Boston: Beacon Press, 1995), 107.

${ }^{5}$ See Michel-Rolph Trouillot, 'North Atlantic Universals: Analytical Fictions, 1492-1945, The South Atlantic Quarterly (Vol. 101/No. 4/ Fall 202), 839-858.

${ }^{6}$ Sibylle Fischer, Modernity Disavowed: Haiti and the Cultures of Slavery in the Age of Revolution (Durham: Duke University Press, 2004), 233.

${ }^{7}$ Aimé Césaire, Return to my Native Land, tr. by John Berger and Anna Bostock (Harmondsworth: Penguin, 1969), 52.

${ }^{8}$ For the 'Grand Peur' across the Caribbean, see Clarence J. Munford and Michael Zeuske. 'Black Slavery, Class Struggle, Fear and Revolution in St. Domingue and Cuba, 1785-1795.' The Journal of Negro History 73, no. 1/4 (1988), 12-32. Different to other journal references, e.g. Note 17

${ }^{9}$ For the spectre of the Haitian Revolution in the ante-bellum USA, see Alfred N. Hunt, Haiti's Influence on Antebellum America Slumbering Volcano in the Caribbean (Baton Rouge: Louisiana State University, 1988); Ashli White, Encountering Revolution: Haiti and the Making of the Early Republic (Baltimore: Johns Hopkins University Press, 2010); Matthew J. Clavin, Toussaint Louverture and the American Civil War: The Promise and Peril of a Second Haitian Revolution (Philadelphia: University of Pennsylvania Press, 2010).

${ }^{10}$ James McCune Smith. A Lecture on the Haytien Revolutions; with a Sketch of the Character of Toussaint L'Ouverture (New York: Daniel Fanshaw, 1841), 3.

${ }^{11}$ For an account of the attribution of Secret History to Sansay, see Jennifer van Bergen, 'Reconstructing Leonora Sansay' (01/03/201), Another World is Possible, http://www.a-w-ip.com/index.php/2010/01/03/reconstructing-leonora-sansay [accessed 17/2/2015].

${ }^{12}$ See e.g. Joan Dayan, Haiti, History, and the Gods (Berkeley: University of California Press, 1995), $169-73$.

${ }^{13}$ Dayan regards the massacre as a brutal but necessary anticolonial measure, an attempt 'to sever the bonds between the former colony and its 'Mother country (Haiti, History, and the Gods, 4). By contrast, Philippe R. Girard, drawing largely on contemporary white racist sources, classifies it as 'genocide' (Philippe R. Girard, 'Caribbean Genocide,' in Patterns of Prejudice (39/2), 138-161, here 140.) Laurent Dubois is considerably more cautious. Citing Dessalines' (probably not unfounded) fears of a white conspiracy as one reason for ordering the massacres of the white French, Dubois states that 'precisely how many perished is difficult to establish' (Laurent Dubois, Avengers of the New World: The Story of the Haitian Revolution, Cambridge, Mass.: Belknap Press of Harvard University Press, 2004, 300). For examples of white supremacist sites which employ the massacres as 'proof' of the inherent savagery of the black race, see e.g. 'The Haitian Holocaust'

https://www.stormfront.org/posterity/race/haiti.html [accessed 3/1/2015]; 'The Horror of Haiti for Southerners: A Timeless Lesson from the Pages of History' http://southernnationalist.com/blog/2012/05/27/the-horror-of-haiti-for-southerners/ [accessed 3/1/2015].

${ }^{14}$ Leonora Sansay, Secret History; or, the Horrors of St. Domigo and Laura, ed. by Michael J. Drexler (Peterborough, ON: Broadview, 2007), 123.

${ }^{15}$ Ibid., 124. The editor of this edition, Michael J. Drexler, seems to regard the fact that 'black on white violence' in the novel is not depicted as 'eyewitness accounts' as evidence of the novel's alleged antiracist bias. (Secret History, 32, note 2).

${ }^{16}$ Ibid., 125.

${ }^{17}$ Elizabeth Maddock Dillon, 'Leonora Sansay and the Revolution in Saint Domingue,' in NOVEL: $a$ Forum on Fiction (Vol. 40/No. 1/2/ 2006/2007), 77-103; here 93. See similarly Tesse P. Liu, 'The Secret beyond White Patriarchal Power: Race, Gender, and Freedom in the Last Days of Colonial Saint-Domingue,' in French Historical Studies (33.3/2010), 387-416; here 410. Woertendyke altogether omits this execution scene from her discussion of the novel, see Gretchen Woertendyke, 'Romance to Novel: a Secret History,' in Narrative (17.3/ 2009), 255-73. There is a pronounced tendency in criticism to downplay the novel's racism or even turn into an anti-racist text. 
${ }^{18}$ Baron de Vastey, The Colonial System Unveiled, tr. by Chris Bongie (Liverpool: Liverpool University Press), 127-8.

${ }^{19}$ Philippe R. Girard, 'Caribbean Genocide,' 4.

${ }^{20}$ See for instance Vastey's gruesome catalogue of torture and execution methods, in M. le Baron de J.

L. Vastey, Notes a M. le baron der V. P. Malouet ... (Cap-Henry: P. Roux, 1814), 8 and even more extensively and nauseatingly with the atrocities attributed to the colonists by name, in The Colonial System Unveiled, 109-23.

${ }^{21}$ Due to its many different versions and appropriations over the centuries, Dustin Kennedy has gone as far as to anachronistically call Stedman's Narrative a 'viral' text (Dustin Kennedy, 'Going Viral:

Stedman's Narrative, Textual Variation, and Life in Atlantic Studies,' Romantic Circles: Circulations: Romanticism and the Black Atlantic

http://www.rc.umd.edu/praxis/circulations/HTML/praxis.2011.kennedy.html [accessed 5/2/2015].

${ }^{22}$ John Gabriel Stedman, Narrative of a Five Years Expedition against the Revolted Negroes of Surinam (London: Johnson, 1813) vol. 1, 60.

${ }^{23}$ Alan Rice. Radical Narratives of the Black Atlantic (London: Continuum, 2003), 139.

${ }^{24}$ Marcus Wood, Blind Memory: Visual Representation of Slavery in England and America, 1780-1865 (Manchester: Manchester University Press), 40.

${ }^{25}$ Saidiya V. Hartman, Scenes of Subjection: Terror, Slavery, and Self-Making in Nineteenth-Century America (New York: Oxford University Press, 1997), 81.

${ }^{26}$ Vastey, The Cololonial System Unveiled, 80; [my alterations], italics in original.

${ }^{27}$ Marlene L. Daut, 'Un-Silencing the Past: Boisrond-Tonnerre, Vastey, and the Re-Writing of the Haitian Revolution, 1805-1817,' South Atlantic Review (74/1)(2009), 35-64; here 51 and 60 (n. 52); my emphasis.

${ }^{28}$ Dayan, Haiti, History, and the Gods, 216. Vastey, The Colonial System Unveiled, 124-5.

${ }^{29}$ James, Black Jacobins, 10. It is likely that James' list of the horrendous tortures and punishments draws - at least partly - on Vastey's lists.

${ }^{30}$ Cf. Jürgen Osterhammel, Die Verwandlung der Welt: Eine Geschichte des 19. Jahrhunderts (Bonn: Bundeszentrale für politische Bildung, 2010), 758.

${ }^{31}$ Anthony Bogues, Empire of Liberty: Power, Desire, and Freedom (Hanover: Dartmouth College Press: University Press of New England, 2010), 114.

${ }^{32}$ Ricardo Seitenfus, 'Haiti is the Proof of the Failure of the International Assistance,' trans. by Dady Chery, http://axisoflogic.com/artman/publish/Article_61939.shtml [accessed 25/8/2014].

${ }^{33}$ For an analysis of the 'Salt is not for Slaves' and the relationship between the horror trope of the zombie and the Haitian Revolution, see Raphael Hörmann, 'Tropen des Terrors: Zombies und die Haitianische Revolution,' in Zeitschrift für Kulturwissenschaften (2014/1), ed. by Gudrun Rath, 61-72. For an overview of the portrayal of Haiti in US cultural production during the US occupation, see Mary A. Renda, Taking Haiti: Military Occupation and the Culture of U.S. Imperialism, 1915-1940 (Chapel Hill: University of North Carolina Press, 2001).

${ }^{34}$ Mimi Sheller, Consuming the Caribbean: From Arawaks to Zombies (London: Routledge, 2003), 168.

${ }^{35}$ For two studies tracing the continuing negative discursive construction of Haiti, see Robert Lawless, Haiti's Bad Press: Origins, Developments, and Consequences (Rochester: Schenkman Books, 1992) and Michael J. Dash, Haiti and the United States: National Stereotypes and the Literary Imagination, second edition, (Houndsmills/New York: Macmillan/St. Martin's Press, 1997).

${ }^{36}$ Michel-Rolph Trouillot, 'The Odd and the Ordinary: Haiti, the Caribbean, and the World,' Cimarrón: New Perspectives on the Caribbean (Vol. 2/ No. 3/ Winter 1990), 3-12, here 6.

${ }^{37}$ Noam Chomsky, 'Introduction,' in: Paul Farmer, The Uses of Haiti (Monroe: Common Courage Press, 2006), 15.

${ }^{38}$ Gina Athena Ulysse, Why Haiti Needs New Narratives: A Post-Quake Chronicle (Middletown; Wesleyan University Press, 2015), 28.

${ }^{39}$ Raphael Hörmann, "'And so the Devil said: 'Ok, it's a Deal”" Das Erdbeben von 2010 und die Dämonisierung der Haitianer und ihrer Geschichte, ' in Tobias Nanz and Johannes Pause, Politiken des Ereignisses: Mediale Formierungen von Vergangenheit und Zukunft (Bielefeld: Transcript, 2015), 6182.

${ }^{40}$ Clavin, 'Race, Rebellion, and the Gothic,' 3.

${ }^{41}$ Ibid., 13.

${ }^{42}$ Gretchen J. Wortendyke, 'Specters of Haiti: Race, Fear, and the American Gothic, 1789-1855.' PhD thesis, Stony Brook University, 2007. 
${ }^{43}$ Ellis Markman, The History of Gothic Fiction (Edinburgh: Edinburgh University Press, 2000), 20544.

${ }^{44}$ H.L. Malchow, Gothic Images of Race in Nineteenth-Century Britain (Stanford: Stanford University Press, 1996), 9-40.

${ }^{45}$ Lisabeth Paravisini-Gebert (2000), 'Colonial and Postcolonial Gothic: The Caribbean,' in Jerrold E Hoggle (ed.), The Cambridge Companion to Gothic Fiction (Cambridge, etc.: Cambridge Univ. Press, 2000), 296-330, here 301.

${ }^{46}$ Dayan, Haiti.

${ }^{47}$ Fischer, Modernity Disavowed. For the term 'Haitian Turn,' see Celucien L Joseph, 'The Haitian Turn': Haiti, the Black Atlantic, and Black Transnational Consciousness.' PhD-thesis. University of Texas, 2012.

${ }^{48}$ Hörmann, 'Tropen des Terrors,' 67-70.

${ }^{49}$ Clavin, 'Race, Rebellion, and the Gothic,' 2

${ }^{50}$ David Brion Davis, 'Impact of the French and Haitian Revolutions,' in David P. Geggus, ed., The Impact of the Haitian Revolution in the Atlantic World (Columbia: University of South Carolina Press, 2001), 5 .

${ }^{51}$ Philip Kaisary, The Haitian Revolution in the Literary Imagination: Radical Horizons, Conservative Constraints. (Charlottesville: University of Virginia Press, 2014).

${ }^{52}$ Frederick Douglass, 'From a Lecture on Haiti. The Haitian Pavilion Dedication Ceremonies Delivered at the World's Fair, in Jackson Park, Chicago, Jan. 2d, 1893 in: Maurice Jackson and Jacqueline Bacon (eds.), African Americans and the Haitian Revolution (New York: Routledge, 2010), 202-211, here 206. For critical engagements with this lecture, see e.g. Woertendyke, 'Specters of Haiti,' 12-14.; Joseph, 'The Haitian Turn,' 118-48. For a comparison of Douglass' official speech at the Haitian Pavilion and the later lecture at Quinn Chapel, see Glen McClish, 'The Spirit of Human Brotherhood', 'The Sisterhood of Nations', and 'Perfect Manhood': Frederick Douglass and the Rhetorical Significance of the Haitian Revolution,' in: Jackson and Bacon, African Americans and the Haitian Revolution, 123-39. For a comparison between Douglass' view of Haiti and Ireland, see Fionnghuala Sweeney. Frederick Douglass and the Atlantic World (Liverpool: Liverpool University Press, 2007), 163-87.

${ }^{53}$ Douglass, 'From a Lecture on Haiti,' 210; emphasis in original.

${ }^{54}$ Marcus Wood. The Horrible Gift of Freedom: Atlantic Slavery and the Representation of Emancipation (Athens: University of Georgia Press, 2010).

${ }^{55}$ Douglass, 'From a Lecture on Haiti,' 206

${ }^{56}$ Ibid., 210

${ }^{57}$ Ibid.

${ }^{58}$ Ibid., 203, 208.

${ }^{59}$ Ibid., 203.

${ }^{60}$ Anonymous, A Particular Account of the Insurrection of the Negroes of St. Domingo..., translated from the French, $4^{\text {th }}$ edition (n.p., nd.), 3-4, 5, 8, 9.

${ }^{61}$ Ibid., 5 .

${ }^{62}$ Ibid.

${ }^{63}$ A Particular Account, 4; emphasis in the original. For the apocryphal nature of the trope of the impaled infant see e.g. Robin Blackburn, 'Haiti, Slavery, and the Age of the Democratic Revolution,' in William \& Mary Quarterly (63/No. 4), 640-74, here 670; Laurent Dubois 'Avenging America: The Politics of Violence in the Haitian Revolution.' In The World of the Haitian Revolution, edited by David P Geggus and Norman Fiering (Bloomington: Indiana University. Press, 2009), 111-24, here 11

${ }^{64}$ Matthew J. Clavin, Toussaint Louverture and the American Civil War: The Promise and Peril of a Second Haitian Revolution (Philadelphia: University of Pennsylvania Press, 2010), 155.

${ }^{65}$ Bryan Edwards, An Historical Survey of the French Colony in the Island of St Domingo... (London, Stockdale, 1797), 70.

${ }^{66}$ Ibid., 77.

${ }^{67}$ Ibid., 64 .

${ }^{68}$ A Particular Account, 8.

${ }^{69}$ 'The Haitian Holocaust,' https://www.stormfront.org/posterity/race/haiti.html [accessed 3/1/2015].

${ }^{70}$ A Particular Account, 4.

${ }^{71}$ Deborah Jenson has argued that the Declaration of Independence and Dessalines' subsequent declarations, which appeared piecemeal in translation in numerous newspapers and journals across the USA, were to a large extent addressed to a US audience (Beyond the Slave Narrative: Politics, Sex, and Manuscripts in the Haitian Revolution (Liverpool: Liverpool University Press, 2011), 122-60). 
${ }^{72}$ Jean-Jacques Dessalines and Louis Boisrond-Tonnerre, The Haitian Declaration of Independence (1804), http://www.nationalarchives.gov.uk/dol/images/examples/haiti/0003.pdf [accessed 28/12/2014], 3; my translation. This is a scan of the only known copy discovered by Julia Gaffield in the National Archives in Kew. For the story of its discovery, see Julia Gaffield, 'Haiti's Declaration of Independence: Digging for Lost Documents in the Archives of the Atlantic World,' The Appendix (2/1) (2014), http://theappendix.net/issues/2014/1/haitis-declaration-of-independence-digging-for-lostdocuments-in-the-archives-of-the-atlantic-world [accessed 10/2/2015).

${ }^{73}$ Dessalines and Boisrond-Tonnerre, The Haitian Declaration of Independence, 4.

${ }^{74}$ Edwards, An Historical Survey, xx.

${ }^{75}$ Lettres du Général Leclerc, commandant en chef de l'armée de Saint-Domingue en 1802, ed. by Paul Roussier (Paris: Sociéte de l'histoire des colonies françaises, 1937), 238, 256; my translation.

${ }^{76}$ From Peter Stephen [Pierre Etienne] Chazotte. Historical Sketches of the Revolutions, and the foreign and Civil Wars in the Island of St. Domingo (1840), in Jeremy D. Popkin (ed.), Facing Racial Revolution: Eyewitness Accounts of the Haitian Insurrection (Chicago: University of Chicago Press, 2007), 345.

${ }_{77}^{7}$ A Particular Account, 3.

${ }^{78}$ Jean-Jacques Dessalines and Juste Chanlatte, Liberté ou la Mort. Proclamation, 28/4/1804. https://haitiandeclarationofindependence.files.wordpress.com/2013/08/dscf9464.jpg [accessed 29/12/2014].

${ }^{79}$ For importance of the trope of the cannibal as a prime ideological justification for the colonisation of the Caribbean, see e.g. Peter Hulme, Colonial Encounters: Europe and the Native Caribbean, $1492-$

1797 (London: Routledge, 1986).

${ }^{80}$ Sheller, Consuming the Caribbean, 148.

${ }^{81}$ Rice, Radical Narratives of the Black Atlantic, 133.

${ }^{82}$ Sheller, Consuming the Caribbean, 151.

${ }^{83}$ Dessalines and Chanlatte, Liberté ou la Mort.

${ }^{84}$ Ibid.

${ }^{85}$ Wedderburn, The Horrors of Slavery, 86.

${ }^{86}$ James, The Black Jacobins, 19.

${ }^{87}$ Wedderburn, The Horrors of Slavery, 82. For Wedderburn's ties with the British early communist revolutionaries, the Spenceans, see Peter Linnebaugh and Marcus Rediker, The Many-Headed Hydra: Sailors, Slaves, Commoners, and the Hidden History of the Revolutionary Atlantic (Boston: Beacon Press, 2000), 287-326; Iain McCalman 'Antislavery and Ultra-Radicalism in Nineteenth-Century England: The Case of Robert Wedderburn.' Slavery \& Abolition 7, no. 2 (1986): 99-117; McCalman, Radical Underworld: Prophets, Revolutionaries, and Pornographers in London, 1795-1840

(Cambridge: Cambridge University Press, 1988), 50-72. For a comparative study of the struggles of the (ex)-slaves in Haiti and Jamaica for land reform see Mimi Sheller, Democracy after Slavery: Black Publics and Peasant Radicalism in Haiti and Jamaica. (London; Oxford: Macmillan Education, 2000).

${ }^{88}$ See e.g. Linebaugh and Rediker, The Many-Headed Hydra, 305-13.

${ }^{89}$ Wedderburn, The Horrors of Slavery, 96.

${ }^{90}$ Rice. Radical Narratives of the Black Atlantic, 11.

${ }^{91}$ Wedderburn, The Horrors of Slavery, 114.

${ }^{92}$ PRO HO 42/192, quoted in Peter Fryer, Staying Power: The History of Black People in Britain (London: Pluto Press, 1986), 223.

${ }^{93}$ Ibid., 116.

${ }^{94}$ Ibid., 81.

${ }^{95}$ Fischer, Modernity Disavowed.

${ }^{96}$ Wedderburn, Horrors, 114, 115.

${ }^{97}$ Ibid., 115.

${ }^{98}$ See Marcus Wood, Slavery, Empathy, and Pornography (Oxford: Oxford University Press, 2002), $152-162$.

${ }^{99}$ Wedderburn, The Horrors of Slavery, 96.

${ }^{100}$ Vastey, The Colonial System Unveiled, 144. 